\title{
Local Potential Integrated Science Video to Improve SPS and Concept Mastery
}

\section{Insih Wilujeng}

Assoc. Prof., Natural Science Education, Graduate Program, Universitas Negeri Yogyakarta, Yogyakarta, Indonesia, insih@uny.ac.id

\section{Gusti Putu Suryadarma}

Prof., Natural Science Education, Graduate Program, Universitas Negeri Yogyakarta, Yogyakarta, Indonesia, suryadarma@uny.ac.id

\section{Ertika}

Natural Science Teacher, State Junior High School, Bantul, Indonesia, faridarahayu15@gmail.com

\section{Wipsar Sunu Brams Dwandaru}

Lecturer, Physics Education Department, Faculty of Mathematics and Natural Sciences, Universitas Negeri Yogyakarta, Indonesia,wipsarian@uny.ac.id

Science learning video integrated with local potentials was developed and tested to improve students' science process skills (SPS) and concept mastery. The learning video was developed for the topic of micro-hydro power (MHP) plant. This study was aimed to determine the effectiveness of the video integrated with the local potential of MHP plant in science learning. A quasi-experimental nonequivalent control group design was used. The population was first-year students of State Junior High School in Bantul Yogyakarta. The cluster random sampling was used to determine the sample. The aspects of SPS measured were observing and communicating, while the aspects of concept mastery measured were memorizing, understanding, and applying. The data of students' SPS and concept mastery were analyzed using multivariate test. The findings revealed that the use of video integrated with local potential of MHP plant was effective to improve students' SPS and concept mastery. This was statistically supported by the average normalized gain for the experimental group (medium category), which was higher than the control group (low category).

Keywords: local potentials, science learning video, SPS, concept mastery, micro hydro power plant 


\section{INTRODUCTION}

In general, natural science is a branch of knowledge that deals with the study of nature; a basis on which students can connect their conceptual understanding with the world (Tillery et al., 2011). In the natural science learning, it is important that students are guided and facilitated to investigate and solve problems. In other words, students learn beyond memorizing concepts by integrating their conceptual knowledge with practical skills (Zeidan \& Jayosi, 2014). The improvement of natural science learning can be achieved by allowing students to have real experiences through activities that may engage them with environment and local potentials around them. This is in accordance with the standards of natural science learning that emphasize on activities and practices in order to help students understanding the physical world (Kubicek, 2005).

This is also locally true in Indonesia. According to the Republic of Indonesia Law Number 20 Year 2003 concerning the National Education System Chapter X Article 36, the curriculum at all educational levels and types of education are developed according to the principles of diversification adjusted to the units of education, local potentials, and students' potential. Hence, the process of learning should incorporate activities that connect students to the real world. As suggested by the Directorate General for Primary and Secondary Education of the Ministry of Education and Culture (2016) schools and the environments around the schools can be organized and managed as effective sources of learning.

Science process skills (SPS) are skills to analyze natural phenomena using particular methods in order to discover and develop new knowledge (Bundu, 2006). According to Rustaman (2003) SPS includes skills driven by cognitive or intellectual, manual, and social aspects. It is also explained by Ozgelen (2012) that SPS is closely related to the development of students' cognitive abilities. Aydogdu et al. (2014) argue that the ability to use SPS in everyday life is very important for students to solve problems found in the midst of fast-growing society. Therefore, improving SPS is an important key in natural science learning. Besides that, mastering SPS will positively affect students' conceptual understanding (Ting \& Siew, 2014). Dahar (1989) states that concepts are building blocks of thinking. When students have truly mastered a particular concept, they have strong foundations in critical thinking. Therefore, concept mastery and SPS are inseparable because they affect each other. It is also argued that integrating natural science learning with local potential can encourage students to thoroughly improve their concepts of Science (Yusnitasari et al., 2020; Dewi et al., 2018). The improvement of deeper concept mastery can only be encouraged if students are enabled to actively participate in learning activities that require them to perform direct observation of objects (Maknun, 2015). So, as a result, the improvement is reflected in students' cognitive learning outcomes. Moreover, teaching and learning strategies can also influence students' concept mastery. Therefore, it is hoped that the integration of local potentials and learning materials can correctly and contextually help students understand concepts (Laurens et al., 2014). This needs to be noticed because natural science concept mastery is still relatively low and improving it is a collective responsibility of practitioners in natural science education (Andriani \& Riandi, 2015). 
Local potentials refer to specific resources found in a particular location that include the potentials of natural resources, human resources, geographical features, culture, and history. Natural resources include various forms of potentials found in the land, water, and air that are needed for human survival and development (Asmani, 2012). Indonesia is the largest archipelago country in the world made of more than ten thousand islands that spread out as major and minor islands (Hanafi et al., 2015). The varieties of geographical and socio-cultural backgrounds, potentials of resources, and available infrastructures are unique characteristics of Indonesia that can be explored in each region (Ministry of Education and Culture, 2013).

In this study, one example of local potentials that can be integrated into natural science learning is the micro-hydro power (MHP) plant, particularly in relation to concepts of energy in systems of life (Rahardini et al., 2017). An MHP plant is a small-scale hydroelectric power (typically less than $100 \mathrm{~kW}$ ) that uses the natural flow of water as its source of energy. As explained by Gunawan et al. (2013) the generation of electricity by an MHP plant can be small natural water resources, e.g.: irrigation flow, stream flow, or waterfall, taking advantage of their heights. Technically, an MHP plant is made up of three main components: water as the source of energy, a turbine, and a generator. The water flow hits the turbine and therefore produces mechanical energy, which turns the generator and later produces electricity (Sukamta \& Kusmantoro, 2013). The MHP plant involved in this research is located in Wukirsari Village, Singosaren, Imogiri, Bantul, Yogyakarta. In this village, the MHP plant uses water flowing through the stream from Opak River.

In this study, the MHP plant is integrated into a learning video. Video can be categorized as a medium of learning that requires the ability to see and hear at the same time. It provides audio-visual information on concepts, principles, procedures, and applications of theoretical knowledge that can help enhance students' understanding of the learning materials (Brame, 2016). Therefore, with the assistance of learning video, the effectiveness of learning can be improved by focusing more on real practices, maximizing efforts to achieve goals of learning in a relatively shorter time, securing students' enthusiasm for learning, and visualizing abstract concepts (Arsyad, 2014). Moreover, the benefit of using a learning video is that the video is able to show a particular process, relationship, or technique (Smaldino, 2014). This is in line with the advantages of using learning media explained by Arsyad (2014) that include the capabilities to (a) make the presentation of messages or information clearer for the improvement of students' learning processes and learning outcomes; (b) improve and secure students' attention in order to boost their learning motivation; (c) help students interact directly with one another and their environment; (d) allow students to learn independently according to their abilities and interests; (e) give solutions to learning obstacles that are related to senses, space, and time; and (f) provide students with equal experiences and opportunities to learn about the world around them.

There are of course many studies that have been conducted to improve SPS and concept mastery of students using various learning media, e.g.: multiple media (Osman \& Vebrianto, 2013); interactive multimedia (Rosamsi et al., 2019); interactive computer 
simulation (Supriyatman \& Sukarnto, 2014); worksheet (Fahyuni et al., 2019); and especially video (Isnayati et al., 2019). However, the use of local potentials integrated with learning video has not been conducted before. This is unfortunate because integration of local potentials and learning materials can broaden students' perspectives and expose them to insights into the physical world around them, so they are able to preserve and develop the environmental potentials (Zainal, 2014).

An integration of the MHP plant into learning has been conducted by visiting the installation plant (Megawati, 2016; Rahardini, 2017). However, several problems were face, i.e.: (a) the allocated time to visit the location of the MHP plant was inefficient; (b) the transportation to take all students to the location of the MHP plant cost too much money; (c) the risks of students getting involved in dangerous situations during the study tour to the MHP plant were high; (d) the weather was unpredictable; (e) handling students was seriously a difficult task; (f) the students paid less attention when the teacher attempted to strengthen their concept mastery; and (g) the students were easily distracted by their peers and lacking of concentration. As a response to these problems, an educational video for natural science learning was therefore developed in this research to give realistic presentations about an MHP plant without the students having to visit it. The educational video is developed for natural science learning and validated by experts. The video contains natural science concepts that are integrated with MHP plant. The video can be accessed in YouTube, which can be watched under the URL of https://www.youtube.com?channel/UCqikSATaTzls2RTqcC5rhvQ or may be searched under the channel Ertika.PLTMH. It is uploaded into YouTube to reach a wider range of audience, especially students from many areas, with the hope that they can learn and understand the MHP plant. The video also contains experimental activities that give examples of learning procedures so that students can easily understand the learning material and turn their knowledge into practice.

Based on the background described above, here we study the effect of using video for natural science learning that is integrated with the local potential of an MHP in improving first-year junior high school students' SPS and concept mastery. Finally, this study is aimed to find out and describe the improvement of students' SPS and concept mastery after the implementation of natural science learning that is integrated with a local potential of an MHP plant through the use of video as a learning medium.

\section{REVIEW OF SELECTED LITERATURES}

The use of local potentials for learning purposes have been conducted by various researchers, e.g.: integration of teaching and learning in climate resilient for urban development (McEvoy, 2019); inclusive education from global concepts to local contexts (Beutel et al., 2018); and the importance of local knowledge in formal education (Ferguson et al., 2019). Analysis of local potential for learning material has been conducted by Situmorang (2016) around the environment of State Senior High School 2 Wonosari Yogyakarta. A study of local potential is also conducted to develop a booklet as a learning material suplement in Agricultural Vocational High School (Rahmatih et al., 2018). Moreover, local potentials have been used in learning to improve students' concept mastery, e.g. see Utami \& Wilujeng (2018) where the science 
worksheet based on Kebumen local potential has been used. On the other hand, local potentials may also be utilized to improve students' SPS as shown by Susilawati \& Agustinasari (2017) where project based learning (PBL) via local potentials have been implemented.

The integration of local potential of MHP in natural science learning had been studied by Megawati (2016) and Rahardini (2017). Their findings revealed that the integration of MHP plant in natural science learning was effective to improve students' concept mastery. Pratama \& Prastyaningrum (2016) investigated the effect of PBL assisted by MHP learning media towards undergraduate students' critical thinking skills and found that the PBL assisted by MHP learning media succeeded in improving students' critical thinking skills.

Using video as a medium makes learning activities more effective and efficient (Hasan et al., 2019; Yip et al., 2019) and may also be used of long distance learning (Chilton, 2019). The use of video for learning has been studied in by Dewi et al. (2019) where video was integrated with local potential and found that the use of the video was effective in improving students' concept mastery. Isnayanti et al. (2019) have studied the influence of guided inquiry learning using tutorial video practicum towards students' SPS. They revealed that the collaboration skills of students are better via the tutorial video practicum. Moreover, Mahule et al. (2017) showed that PhET short video simulation through inquiry training learning model improved students' SPS.

\section{METHOD}

\section{Testing Instrument}

SPS are assessed during each activity of learning using observation instruments. Specifically, this research focused on two types of basic SPS. First, observing skill that includes the abilities of students to use their senses to pay attention to the video and collect relevant information. Second, communicating skill that includes the abilities of students to describe the results of their observations in the form of tables as provided in the students' worksheets, and also explain and discuss the information obtained from their observations during learning activities. Observation instruments to assess students' observing and communicating skills use the method of a non-test assessment (Dimyati \& Mujiono, 2009; Rahman \& Majumder, 2014). Generally, basic SPS includes the abilities to observe, classify, predict, conclude, and communicate. However, in this study only observing and communicating skills are involved adapting the development research conducted by Megawati (2016) and shown in Table 1. 
Table 1

Aspects and Indicators of SPS (Megawati, 2016)

\begin{tabular}{ll}
\hline Aspects & Item Indicators \\
\hline \multirow{2}{*}{ Observation } & Using human's five senses. \\
& Collecting relevant facts. \\
\hline \multirow{2}{*}{ Communication } & Explaining the result of observation. \\
& Discussing the result of observations. \\
\hline
\end{tabular}

Next, the instrument to measure students' concept mastery is a multiple-choice test that consisted of 20 items. The assessment of students' concept mastery is commonly based on the categories and human cognitive processes that include the aspects of memorizing, understanding, applying, analyzing, evaluating, and creating (Anderson \& Krathwol, 2001). However, only aspects of memorizing, understanding, and applying are assessed. These aspects are divided into 20 indicator items as shown in Table 2.

Table 2

Aspects and Indicators of Students' Concept Mastery adapted from Megawati (2016)

\begin{tabular}{ll}
\hline Aspects & Item Indicators \\
\hline Memorizing & Stating the unit of Energy. \\
\hline Enderstanding & Explaining the definition of Energy. \\
& Explaining the forms of energy found in a motorcycle. \\
& Explaining the advantages of an MHP plant. \\
& Giving examples of renewable energy sources. \\
& Giving examples of non-renewable energy sources. \\
& Explaining energy transformations in an object or an electronic device. \\
& Giving examples of energy transformations when someone is running. \\
& Explaining energy transformations found in an MHP plant. \\
& Explaining the law of energy conservation in energy transformations. \\
& Explaining the mechanical energy when water falls into a turbine. \\
& Explaining factors influencing the amount of potential energy. \\
& Explaining factors influencing the amount of kinetic energy. \\
& Measuring the height of an object using the potential energy. \\
& Measuring the amount of kinetic energy in a certain event. \\
& Measuring the speed of an object using the kinetic energy. \\
Measuring the potential energy via the mechanical energy formula.
\end{tabular}

\section{Data Analysis Technique}

The improvement of SPS and concept mastery obtained from the results of observations and the multiple-choice test can be measured using the analysis of normalized gain $(\mathrm{g})$. By involving pre-test and post-test scores, the analysis of $g$ will prove the effectiveness of the video used for natural science learning integrated with the MHP plant in improving students' SPS and concept mastery. $g$ is determined using equation (1). The results of the analysis of $g$ are converted into categories according to Table 3.

$$
\mathrm{g}=\text { (posttest score }- \text { pretest score) / (maximum score - pretest score). }
$$


Table 3

Categories of $g$ Scores (Hake, 1999)

\begin{tabular}{lll}
\hline No. & Score $(g)$ & Categories \\
\hline 1 & $g>0.7$ & High \\
2 & $0.3 \leq g \leq 0.7$ & Medium \\
3 & $g<0.3$ & Low \\
\hline
\end{tabular}

This study used a quasi-experimental method with a non-equivalent control group design and involved two sample classes: the experimental and control groups. The necessary data were obtained before and after the use of video for natural science learning. The data are collected through observation instruments and multiple-choice tests that assess the SPS and concept mastery aspects, respectively. These two types of data are taken from the experimental and control groups. Students in the experimental and control groups used video and PowerPoint (PPT) images-narration, respectively. Dependent variables in this study are SPS and concept mastery. To statistically analyze the effectiveness of the use of video in improving students' SPS and concept mastery, the multivariate test is carried out using SPSS version 22.

\section{FINDINGS AND DISCUSSION}

\section{Preliminary Tests}

Preliminary tests are conducted before the data are analyzed with MANOVA. They are multivariate tests for normality and homogeneity (homogeneous variance-covariance matrices).

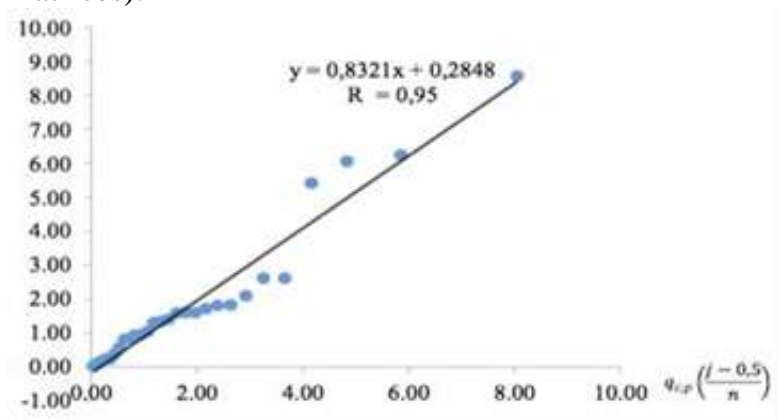

Figure 1

SPS and Concept Mastery Chi-Square Plots of the Control Group 


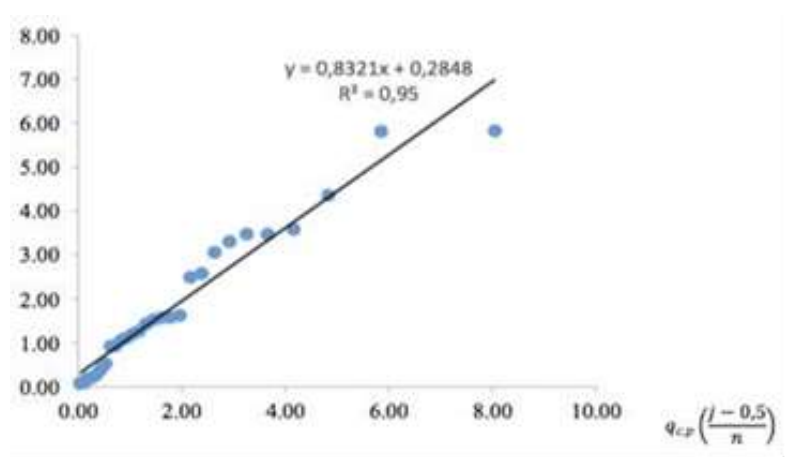

Figure 2

SPS and Concept Mastery Chi-Square Plots of the Experimental Group

\section{The Multivariate Test for Normality}

The assumption of multivariate normal distribution is checked using the graphs of chisquare plots by comparing the Mahalanobis squared distance values $\left(d_{-} j^{\wedge} 2\right)$ against the corresponding quantities of the chi-square quintiles $(q c, p((j-0.5) / \mathrm{n}))$. The graphs of chi-square plot as the results of data analysis for sample classes in each school are shown in Figures 1 and 2.

\section{Multivariate Test for Homogeneity}

In order to analyze the data using MANOVA, it is required that the variance-covariance matrices of the dependent variables are homogeneous (equal). In this study, the homogeneity of the variance-covariance matrices assumption is tested by means of the Box's M Test in SPSS. The results are presented in Table 4.

Table 4

Box's Test M Result

\begin{tabular}{llllll}
\hline No. & Test & Score & F & Sig. & Conclusion \\
\hline 1 & Box's M Test & 2.674 & 0.856 & 0.463 & $\mathrm{H}_{0}$ accepted \\
\hline
\end{tabular}

If the calculation to determine the homogeneity of the variance-covariance matrices uses the significance level of 0.05 then it is expected that the value is greater than 0.05 . The analysis using the Box's $M$ test found that the value was greater than 0.05 , which is at the significance level of 0.463 . Thus, it can be concluded that the population variancecovariance matrices of the different groups of analysis are homogeneous.

\section{MANOVA}

MANOVA can be performed only when two requirements as described above have been met. In this research, this method of data analysis was used to prove whether the significant improvements of students' SPS and concept mastery are affected by the use of the learning. Decisions related to the results of MANOVA are made based on the significance values demonstrated by multivariate tests that included Pillae Trace, Wilk 
Lambda, Hotelling Trace, and Roy's Largest Root. The results of MANOVA for this study are presented in Table 5.

Table 5

Multivariate Analysis Result

\begin{tabular}{lllllll}
\hline Effect & & Value & F & Hypothesis df & Error df & Sig. \\
\hline \multirow{4}{*}{ Intercept } & Pillai's Trace & 0.879 & $192.459^{\mathrm{a}}$ & 2.000 & 53.000 & 0.000 \\
& Wilks' Lambda & 0.121 & $192.459^{\mathrm{a}}$ & 2.000 & 53.000 & 0.000 \\
& Hotelling's Trace & 7.263 & $192.459^{\mathrm{a}}$ & 2.000 & 53.000 & 0.000 \\
& Roy's Largest Root & 7.263 & $192.459^{\mathrm{a}}$ & 2.000 & 53.000 & 0.000 \\
\hline \multirow{4}{*}{ Class } & Pillai's Trace & 0.261 & $9.346^{\mathrm{a}}$ & 2.000 & 53.000 & 0.000 \\
& Wilks' Lambda & 0.739 & $9.346^{\mathrm{a}}$ & 2.000 & 53.000 & 0.000 \\
& Hotelling's Trace & 0.353 & $9.346^{\mathrm{a}}$ & 2.000 & 53.000 & 0.000 \\
& Roy's Largest Root & 0.353 & $9.346^{\mathrm{a}}$ & 2.000 & 53.000 & 0.000 \\
\hline
\end{tabular}

According to the results of MANOVA, the significance values shown by Pillae Trace, Wilk Lambda, Hotelling Trace, and Roy's Largest Root are all at the level 0.000. If the level of significance is set at 0.05 , then this means that the values obtained from the MANOVA tests are less than 0.05 . Therefore, there are significant differences between the experimental group that was taught with the use of video and the control group that was taught using PPT. In conclusion, the use of video was effective to improve the students SPS and concept mastery. In addition, to the series of multivariate tests, tests of between-subjects effects are also performed to prove whether the use of video is really able to improve the two dependent variables being measured. The results of tests of between-subjects effects are presented in Table 6.

Table 6

Test results of Between-Subject Effects

\begin{tabular}{lllllll}
\hline \multirow{2}{*}{ Source } & Dependent Variable & $\begin{array}{l}\text { Type III Sum } \\
\text { of Square }\end{array}$ & df & $\begin{array}{l}\text { Mean } \\
\text { Square }\end{array}$ & F & Sig. \\
\hline Corrected & Gainscore_SPS & $0.354^{\mathrm{a}}$ & 1 & 0.345 & 11.710 & 0.001 \\
Model & Gainscore_CM & $0.349^{\mathrm{b}}$ & 1 & 0.349 & 10.984 & 0.002 \\
\hline \multirow{2}{*}{ Intercept } & Gainscore_SPS & 6.459 & 1 & 6.459 & 213.655 & 0.000 \\
& Gainscore_CM & 8.053 & 1 & 8.053 & 253.347 & 0.000 \\
\hline \multirow{2}{*}{ Class } & Gainscore_SPS & 0.354 & 1 & 0.354 & 11.710 & 0.001 \\
& Gainscore_CM & 0.349 & 1 & 0.349 & 10.984 & 0.002 \\
\hline \multirow{2}{*}{ Error } & Gainscore_SPS & 1.633 & 54 & 0.030 & - & - \\
\hline \multirow{2}{*}{ Total } & Gainscore_CM & 1.716 & 54 & 0.032 & & - \\
\hline \multirow{2}{*}{ Corrected } & Gainscore_SPS & 8.446 & 56 & - & - & - \\
Total & Gainscore_CM & 10.118 & 56 & & - & - \\
\hline
\end{tabular}

As seen in Table 10, the $\mathrm{g}$ scores for SPS and concept mastery reach the significance values at 0.001 and 0.002 , respectively. If the level of significance is set at 0.05 , then this means that the values obtained from tests of between-subjects effects are less than 0.05 . Specifically, the significance value reached by the gain scores for SPS is less than 0.05 , and this can be interpreted that there are significant differences in students' SPS 
affected by the use of video. The significance value reached by the gain scores for concept mastery is also less than 0.05 . It can also be interpreted that there are significant differences in students' concept mastery affected by the use of the learning video for natural science learning that was integrated with the local potential of an MHP plant.

\section{The Analysis of SPS}

The observation results of students' SPS are presented in Tables 7 and 8 . The average score of students' SPS based on post-treatment observation is higher than the pretreatment observation. It may also be observed that students' SPS are improved in the experimental and control groups. Moreover, the $g$ scores of the experimental and control groups are 0.42 and 0.22 , which are categorized as medium and low, respectively. The improvement of students' SPS in the experimental group is higher than the control group.

Table 7

Results of Students' SPS Before and After the Treatment

\begin{tabular}{lllll}
\hline \multirow{2}{*}{ Components } & \multicolumn{2}{l}{ Experimental Class } & \multicolumn{2}{l}{ Control Class } \\
\cline { 2 - 5 } & Pretest & Posttest & Pretest & Posttest \\
\hline Total Students & 28 & 28 & 28 & 28 \\
Average score of SPS & 58.57 & 75.96 & 62.14 & 70.60 \\
The highest score of SPS & 45.00 & 63.00 & 45.00 & 58.00 \\
The lowest score of SPS & 70.00 & 88.00 & 70.00 & 85.00 \\
Variance & 55.29 & 57.36 & 54.49 & 48.47 \\
Standard Deviation (SD) & 7.43 & 7.57 & 7.38 & 6.96 \\
\hline
\end{tabular}

Table 8

Average g Scores of students' SPS for the Experimental and Control Groups

\begin{tabular}{llll}
\hline \multirow{2}{*}{ No. } & \multirow{2}{*}{ Scores } & Groups & \\
\cline { 3 - 4 } & & Experimental & Control \\
\hline 1 & Pretest & 58.57 & 62.14 \\
2 & Posttest & 75.96 & 70.60 \\
3 & $g$ & 0.42 & 0.22 \\
4 & Category & Medium & Low \\
\hline
\end{tabular}




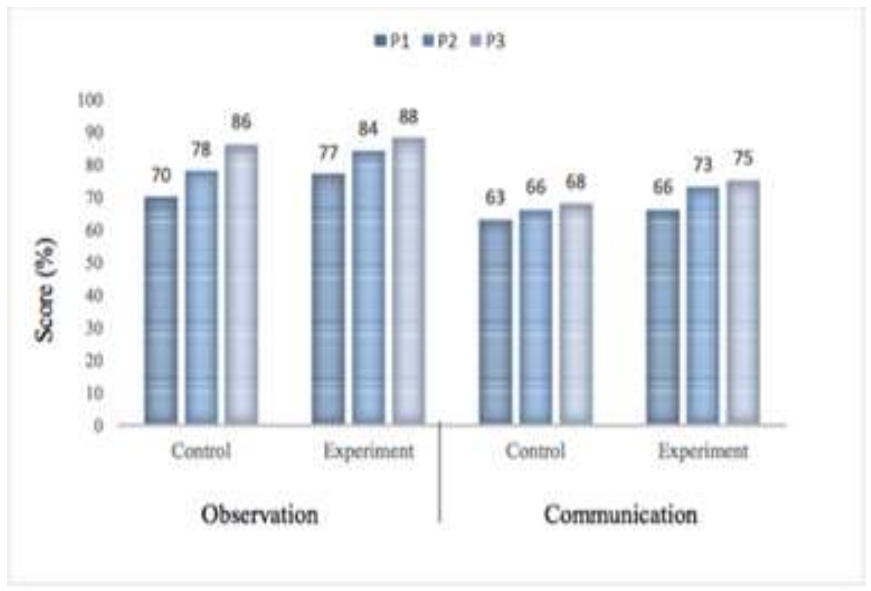

Figure 3

Histograms of Pretest and Posttest Scores Based on Each Aspect of SPS

Next, regarding the data obtained from post-treatment observation (see Figure 3), it can be seen that the average scores of students' SPS in Meeting 1 (P1), Meeting 2 (P2), and Meeting 3 (P3) improve significantly during learning activities. The two basic SPS assessed in this study, i.e.: observing and communicating skills, showed better improvement, which is in accordance with the results in Mahule et al. (2017). Especially in the experimental group, students are able to proceed with the opportunities for experimentation following the procedural steps they could directly see and listen throughout the video. This made learning activities more efficient because students could easily understand what they needed to do in the classroom. As stated by Settlage (2012), SPS are essential abilities that students need to attain in order to develop deeper understanding of science concepts, effective communication with their peers, and good cooperation.

\section{The Analysis of Concept Mastery}

Students' concept mastery is measured using pre- and post-tests. Both of the tests consisted of multiple choice consisting of 20 items. Pre-tests are conducted before the treatment procedures in the experimental and control groups of the selected schools. The purpose of administering the pre-tests to students is to determine the initial level of their concept mastery of Energy in the Systems of Life before using the learning video. Then, post-tests are conducted after the treatment procedures to determine the final level of students' concept mastery. The pre- and post-test scores for the assessment of students' concept mastery and the average $\mathrm{g}$ scores of the experimental and control groups are presented in Table 9. 
Table 9

Results of Students' Concept Mastery Before and After the Treatment

\begin{tabular}{lllll}
\hline \multirow{2}{*}{ Components } & \multicolumn{2}{l}{ Experimental Class } & \multicolumn{2}{l}{ Control Class } \\
\cline { 2 - 5 } & Pretest & Posttest & Pretest & Posttest \\
\hline Total Students & 28 & 28 & 28 & 28 \\
Average score concept mastery & 49.64 & 70.71 & 56.07 & 68.92 \\
The highest score of concept mastery & 20.00 & 50.00 & 30.00 & 50.00 \\
The lowest score of concept mastery & 70.00 & 95.00 & 70.00 & 75.00 \\
Variance & 157.27 & 138.36 & 71.03 & 41.40 \\
Standard Deviation (SD) & 12.54 & 11.76 & 8.42 & 6.43 \\
\hline
\end{tabular}

According to the obtained data, especially after the treatment process, scores for students' concept mastery show significant improvement in both the experimental and control groups. This is shown by the average, highest, and lowest scores that increase for each group. According to the $\mathrm{g}$ analysis, the $\mathrm{g}$ scores of the experimental and control groups are 0.58 and 0.27 , which are categorized as medium and low, respectively. This reveals that the improvement of students' concept mastery in the experimental group is significantly higher than the control group. These results are presented in Table 10. Based on the information displayed in Table 7, the post-test score is higher than the pretest score for both experimental and control groups indicating that students' concept mastery are significantly improved. Moreover, the g scores of students' concept mastery in the experimental and control groups are 0.42 and 0.39 , which fall in the medium and low categories, respectively.

Table 10

Average g Scores for the Experimental and Control Groups of Concept Mastery

\begin{tabular}{llll}
\hline \multirow{2}{*}{ No. } & \multirow{2}{*}{ Scores } & Groups & \\
\cline { 3 - 4 } & & Experimental & Control \\
\hline 1 & Pretest & 49.64 & 56.07 \\
2 & Posttest & 70.71 & 68.92 \\
3 & $g$ & 0.42 & 0.29 \\
4 & Category & Medium & Low \\
\hline
\end{tabular}

The results also correspond with the pedagogical benefits of video for teaching and learning that had been revealed by previous studies. Video as a learning medium is able to help students understand the learning content because it is presented through visual and sound. Furthermore, students are allowed to extend and enhance their learning time by watching the video again at home, and thus they are able to gather more information. With its audio-visual characteristic, video makes students able to grasp new information quickly and easily, encourage students' imagination and thinking skills. Furthermore, video is able to deliver information through realistic representation. Therefore, students regardless of their levels of intelligence are allowed to learn from the video at the same time and show desired responses in accordance with the learning objectives. In summary, learning through video is effective to increase students' interest and help them develop intrinsic motivation to learn (Arsyad, 2014; Riyana, 2007; Munadi, 2013; Asyhar, 2012; Smaldino, 2014). 
In this study, video as a learning medium is able to improve students' concept mastery in accordance with the results in Dewi et al. (2019). This study measures three aspects of concept mastery, viz.: memorizing, understanding, and applying. The process of memorizing is a low cognitive level and the findings of this study revealed that students achieved the highest score in this aspect. To make learning more meaningful, the aspect of memorizing must be integrated into learning activities by connecting students' memorizing abilities to the aspect of knowledge as a wider scope and not as a separate and isolated one (Rebekah et al., 2010). Undoubtedly, students are required to improve their thinking skills. However, it is likely that they are unable to construct higher levels of concepts if they lack of fundamental information because they have trouble memorizing (Rustaman, 2005). The improvement of each aspect of students' concept mastery is shown in Figure 4.

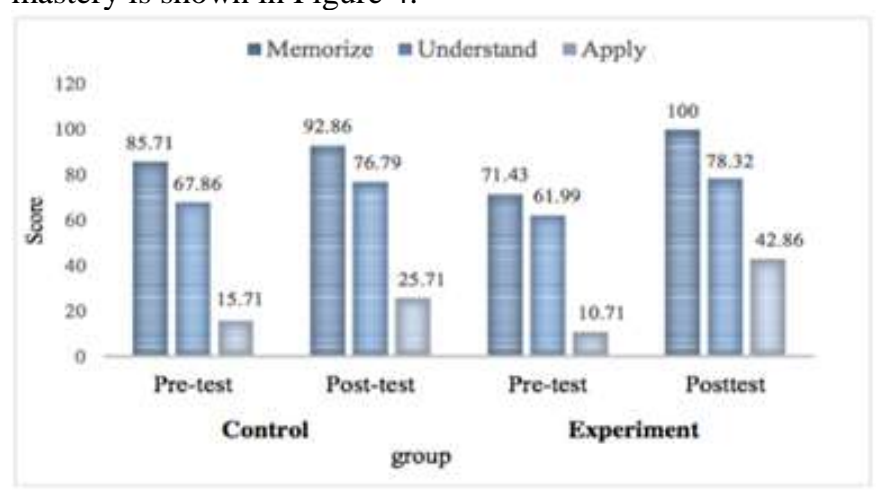

Figure 4

Histogram of Pre-test and Post-test Scores Based on Each Aspect of Concept Mastery

The next aspect that shows significant improvement is understanding. This aspect requires students to have sufficient understanding in order to be able to arrange and organize the concepts learned. They must be able to answer questions or solve problems with the right information or solutions based on their knowledge. This means that after the phase of memorizing, students need to mentally and thoroughly perceive the intended meanings or significance of the concepts learned (Ben et al., 2008). Regarding the aspect of understanding, both experimental and control groups showed significant improvement. Learning using video also makes students understand concepts more easily compared to learning only through explanatory PPT (Rustaman, 2005).

The last aspect of concept mastery considered in this study is applying. The findings show that this aspect achieves the lowest score after memorizing and understanding. Applying mainly refers to cognitive processes where students are able to perform procedural actions in solving problems (Anderson \& Krathwohl, 2001). Thus, it is closely related to procedural knowledge, including the abilities to carry out a certain task by following the procedure and implement certain concepts in real-life situations (Bloom, 1956). Carrying out a certain task by following the procedure is the manifestation of a cognitive process in dealing with problems, in which students know 
what to do and how to do it in order to achieve satisfactory results (Jong et al., 1996). Therefore, applying is a continuous process that starts from the knowledge of certain formulas or procedures to solve problems. As a consequence, if students face difficulties in understanding procedures to solve certain problems, then they negatively affect the aspect of applying.

As one of the dependent variables in this study, students' concept mastery is influenced by some psychological factors, i.e.: intelligence, attention, interest, attitude, motivation, maturity, and fatigue (Putra et al., 2014). Students' concept mastery in the control group, especially for the aspects of memorizing and understanding, were not satisfactory because knowledge was transferred only through PPT. Students' abilities to apply their knowledge are also not satisfactory because formulas found in an MHP are not demonstrated. The aspects of memorizing, understanding, and applying are identified as the most basic cognitive processes in concept mastery (Anderson \& Krathwol, 2001). Then, building concepts in students need more active processes than just delivering concepts to them (Arends, 2008). Students are required to make attributes or patterns of certain concepts and connect them to knowledge that they already have (Barba, 1998). Finally, it can be stated that the results of this research correspond to Jeenthong's findings (2014), in which it was concluded that the students involved in meaningful experiences with proper guidance were able to show better understanding of real-life contexts and better concept mastery than the students taught only with conventional methods.

Overall, this study contributes significantly to improving students' SPS and concept mastery via MHP plant local potential integrated in science learning video. Hence, the use of science learning video integrated with local potential is recommended in order to improve students' SPS and concept mastery. Moreover, the integration of local potential into science learning video overcomes prior problems of visiting the actual MHP installation. Students may replay the video many times at any time and teachers do not have difficulty in handling the students.

\section{CONCLUSIONS}

Based on the results of multiple statistical tests on the quantitative data collected in this study, it can be concluded that the use of video for natural science learning that is integrated with the local potential of an MHP plant is effective to improve SPS and concept mastery of students. Furthermore, the improvements of students' SPS and concept mastery in the experimental group are significantly higher than in the control group. This study encourages students to be taught not just by PPT presentation and narration, but also using video learning media in order to improve their SPS and concept mastery. Moreover, by integrating local potentials of the surrounding environment it expected that this result would give students the knowledge to care, protect, and improve their environment. A limitation in the use of learning video is the lack of hands on approach to the topic of MHP plant compared to directly visiting the plant. Hence, it is interesting to compare or even combine the two learning methods for further studies. 


\section{ACKNOWLEDGMENTS}

The authors would like to thank the Graduate Program, Pascasarjana, Universitas Negeri Yogyakarta for funding this research.

\section{REFERENCES}

Anderson, L. W., \& Krathwohl, D. R. (2001). A taxonomy for learning, teaching, and assessing. London: Longman.

Andriani, Y., \& Riandi (2015). Increasing concept mastery of students through argument driven inquiry via integrated Science learning in grade VII of Junior High School (SMP). Edusains, 7(2), 114-120.

Arends, R. I. (2008). Learning to teach. Yogyakarta: Pustaka Belajar.

Arifin, Z. (2014). Education research. Bandung: PT Remaja Rosdakarya.

Arsyad, A. (2014). Learning media. Jakarta: PT Raja Grafindo Persada.

Asmani, J. M. (2012). A guidebook for internalizing character education in schools. Yogyakarta: Diva Press.

Asyhar, R. (2012). Creative in developing learning media. Jakarta: Garung Persada Press.

Barba, R. H. (1998). Science in the multicultural classroom. Boston: Allyn and Baco.

Beutel, D., Tangen, D., \& Carrington, S. (2018). Building bridges between global concepts and local contexts: implications for inclusive education in Nepal, Sri Lanka, and Bangladesh. International Journal of Inclusive Education, 23(1), 109-124.

Brame, C. J. (2016). Effective educational videos: principles and guidelines for maximizing student learning from video content. Essay CBE-Life Sci. Edu, 15(6), 1-6.

Bundu, P. (2006). Assessment of science process skills and attitudes in science learning. Jakarta: Ministry of National Education.

Chilton, M. A. (2019). Technology in the classroom: using video links to enable long distance experiential learning. Journal of Information Systems Education, 23(1), 51-62.

Dewi, E. C., Suryadarma, I. G. P., \& Wilujeng, I. (2018). Using video integrated with local potentiality to improve students' concept mastery in natural science learning. $J$. Phys.: Conf. Ser., 1097, 012001.

Dimyati, \& Mudjiono. (2006). Learn and learning. Jakarta: Rieneka Cipta.

Fahyuni, E. F., Rusijono, \& Masitoh, S. (2019). The guided-inquiry-worksheet stimulating process skills and concept understanding in Indonesia junior high school. Asian Journal of Education and Social Studies, 3(1), 1-10. 
Ferguson, B. G., Morales, H., Chung, K., \& Nigh, R. (2019). Scaling out agroecology from the school garden: the importance of culture, food, and place. Agroecology and Sustainable Food Systems, 43(7-8), 724-743.

Gunawan, A., Oktafeni, A., \& Khabzli, W. (2013). Monitoring of micro hydro power plants. Jurnal Rekayasa Elektrika, 10(4), 202-206.

Hake, R. R. (1999). Analyzing change/gain scores. Indiana: Indiana University.

Hasan, R., Palaniappan, S., Mahmood S., Shah, B., Abbas, A., \& Sarker, K. U. (2019). Enhancing the teaching and learning process using video streaming servers and forecasting techniques, Sustainability, 11(7), 2049.

Isnayanti, R. S., Hardyanto, W., \& Sutikno. (2019). The influence of assistance of helped guided inquiry methods tutorial video practicum on the process of student science skills. Journal of Innovative Science Education, 8(1), 30-36.

Jeenthong, T., Ruenwongsa, P., \& Namkang. (2014). Promoting integrated science process skills through betta-live science laboratory. Procedia - Social and Behavioral Sciences, 116, 3292-3296.

Jessica H., \& Anthony R. (2015). Life cycle assessment of a mini hydro power plant in Indonesia: a case study in Karai River. 22nd CIRP Conference on Life Cycle Engineering, 29, 444-449.

McEvoy, D., Iyer-Raniga, U., Ho, S., Mitchell, D., Jegatheesan, V., \& Brown, N. (2019). Integrating teaching and learning with inter-disciplinary research in support of climate resilient urban development. Sustainability, 11(23), 6701.

National Education Ministry. (2013). A guide to the development of integrated science learning. Jakarta: Directorate of Junior High School Development.

Kubicek, J. P. (2005). Inquiry-based learning, the nature of science, and computer technology: new possibilities in science education. Canadian Journal of Learning and Technology, 31(1).

Laurens, T., Laamena, C., \& Matitaputty, C. (2014). Development a set of instructional learning based realistic mathematics education and local wisdom. Proceedings of International Seminar Innovation in Mathematics and Mathematics Edu, 66, 571-576.

Maknun, J. (2015). The implementation of generative learning model on physics lesson to increase mastery concepts and generic science skills of vocational students. American Journal of Educational Research, 3(6), 742-748.

Megawati, D. M. (2016). Developing teaching kit on the use of micro-hydro generator in remote area. Jurnal Inovasi Pendidikan IPA, 3(1), 22-29.

Ministry of Education and Culture. (2013). Republic of Indonesia Ministry of Education and Culture Regulation Number 18A of 2013 concerning the implementation of the curriculum. Jakarta: Ministry of Education and Culture. 
Munadi, Y. (2013). Learning media as a new approach. Jakarta: GP Press Group.

Osman, K., \& Vebrianto, R. (2013). Fostering science process skills and improving achievement through the use of multiple media. J. of Baltic Sci. Edu., 12(2), 191-204.

Pratma, H., \& Prastyaningrum, I. (2016). The influence of project based learning model assisted by microhydro power plant learning media on critical thinking ability. Journal of Physics Research and Its Application, 6(2), 2016.

Putra, R. A., Fransisca, S., \& Redjeki, S., Adianto. (2014). The analysis of concept mastery and critical thinking skills on invertebrate zoology course. International Journal of Science and Research, 3(3), 498-502.

Rahardini, R. R. B. (2017). The effect of science learning integrated with the local potential of micro hydro power plants on science process skills and concept mastery (Unpublished master thesis). Yogyakarta: UNY.

Rahardini, R. R. B., Suryadarma I. G. P., \& Wilujeng, I. (2017). The effect of science learning integrated with local potentials to improve science process skills. AIP Conference Proceedings, 1868(1), 080008.

Rebekah, E. S., Bayen, U. J., \& Martin, C. (2010). The cognitive processes underlying event- based prospective memory in school age children and young adults: a formal model-based study. Article Development Psychology, 46(1), 230-244.

Riyana, C. (2007). A guide to develop video media. Jakarta: P3AI UPI.

Rosamsi, S., Miarsyah, M., \& Ristanto, R. H. (2019). Interactive multimedia effectiveness in improving cell concept mastery. J. of Biology Education, 8(1), 56-61.

Rahman, S., \& Majumder, M. A. A. (2014). Is it assessment of learning or assessment for learning? South East Asia Journal of Public Health, 4(1), 72-74.

Rahmatih, A. N., Yuniastuti, A., \& Susanti, R. (2018). Booklet development based on potency study and local problem as teaching material supplements of Agriculture vocational school. 3rd Biology Education and Science National Seminar Proceeding.

Rustaman. (2005). Development of competencies (knowledge, skills, attitudes, and values) through biological practicum activities. Bandung: FMIPA UPI.

Settlage, J., \& Sherry, S. (2012). Teaching science to every child: using culture as a starting point. London: Routledge

Smaldino, S. E. (2014). Instructional technology and media for learning. Pearson.

Supriyatman, \& Sukarno. (2014). Improving science process skills (SPS) science concept mastery (SCM) prospective student teachers through inquiry learning instruction model by using interactive computer simulation. International Journal of Science and Research, 3(2), 6-9.

Sukamta, Sri, \& Kusmantoro, A. (2013). Planning of micro hydro power plant in Jantur Tabalas East Kalimantan. Jurnal Teknik Elektro, 5(2). 
Tillery, B., Enger, E., \& Ross, F. (2011). Integrated science. New York: Mc Graw Hill Connect Learn Succeed.

Utami, S., \& Wilujeng, I. (2018). Effectiveness of science worksheet based on Kebumen potency in the environment care attitude achievement and concept mastery. E-Journal Pendidikan IPA, 7(7), 348-354.

Yip, J., Wong, S.-H., Yick, K.-L., Chan, K., \& Wong, K.-H. (2019). Improving quality of teaching and learning in classes by using augmented reality video. Computers \& Education, 128, 88-101.

Yusnitasari, A., Sarwi, \& Isnaeni, W. (2020). Concept mastery of ethno science based integrated science and life skills development of elementary school students. Journal of Primary Education, 9(1), 93-101.

Zeidan, A. H., \& Majdi, R. J. (2014). Science process skills and attitudes toward science among Palestinian secondary school students. World Journal of Education, 5(1), 13-24. 